\title{
Review Acts Of Corruption Through The Perspectives Of The Ethics Of Public Administration Theory
}

\author{
$1^{\text {st }}$ Trenda Aktiva Oktariyanda \\ Department of Public Administration \\ Faculty of Social Sciences and Law \\ Universitas Negeri Surabaya \\ Surabaya, Indonesia \\ trendaoktariyanda@unesa.ac.id
}

\author{
$2^{\text {nd }}$ Thelma Wawointana \\ Department of Public Administration \\ Faculty of Social Science \\ State University of Manado \\ Manado, Indonesia \\ thelmawaointana@unima.ac.id
}

\author{
$3^{\text {rd }}$ Kahar Fakhri \\ Department of Public Administration \\ Faculty of Social Science \\ State University of Makassar \\ Makassar, Indonesia \\ fakhri.kahar@unm.ac.id
}

\begin{abstract}
A proliferation of corruption cases are massive and occurred over and over again, has demonstrated to us that there is a serious pathology of the bureaucracy and insubordination against the ethics of public administration in Indonesia. With the emergence of cases of corruption, then the necessary enforcement and application of the ethics of public administration that is strong and consistent. In the ethics of public administration theory approach uses two perspectives of the ethics of public administration, that is the perspective of teleology and deontology perspective. Through these perspectives can be when they are clear that acts of corruption are not contrary to the ethics of public administration. The ethics of public administration which is supposed to be is focused on accountability, responsiveness, transparency, corporate responsibility, and law enforcement that could block the opportunity for public officials to commit corruption eradication strategy so corruption became more effective.
\end{abstract}

Keywords-Corruption, Ethics of Public Administration, Ethical Perspective

\section{INTRODUCTION}

Speaking of acts of corruption, collusion, and nepotism in Indonesia, it is not a new thing in our minds. Refer to the bombastic of corruption, how many times the print and electronic media to preach and discuss corruption in Indonesia, how many public officials ranging from the legislative, Executive and judiciary that has already spread to the public, but until now still "faded" aka unresolved by the KPK. We take for example the cases of corruption of which was "stale" until a still-warm, for example: corruption case Century Bank, corruption of Haj pilgrims fund of the Ministry of Religious Affairs 2011-2013, bribery of the Ministry of Energy and Mineral Resources 2013, cases such as the Hambalang project and Nazaruddin case pensions athletes Palembang bribery case, bribery case of the National Sports Week in Riau 2012, corruption case of the Indonesian Barbour II National Company, corruption of the Soft Certificate in Bank of Indonesia Liquidity Assistance, corruption Garuda Plane 2005-2014 and others [1]. This does not include cases of corruption that have not been detected, because there is a strong indication that there are still many cases of corruption that still has not been revealed.

Corruption is an important phenomenon in most societies since it weakens citizens' trust in the administrative and the political systems. According to Transparency International, it can be defined as The abuse of entrusted power for private gain. Corruption can be classified as grand, petty and political, depending on the amounts of money lost and the sector where it occurs [2]. Corruption can be broadly defined as a departure from public rules or laws for private gain. Not only it seriously damages the efficiency and effectiveness of public services, but also weakens citizens' confidence in public institutions, compromising the quality of democracy. Values of public interest, equality, transparency, legality, justice or responsibility are put into question as certain actors with privileged access to public resources are favored [3].

The dominant cause of stick it out cases of maladministration (bureau pathology), such as acts of corruption according to Islamy [4] is the policy of the Government is not transparent, low professionalism apparatus, tightening against social control, the lack of participatory management, consumerist and hedonistic ideology spreading, as well as pragmatic and realistic among officials and Yet the existence of a code of conduct that came into force for reform in all sectors of reward and punishment is accompanied by an open, fair, and firm.

Criminal acts of corruption in Act No. 31 of the year 1999 contained core offense (bestandeel delict) the form of tort law (article 2) and abuse of authority (Clause 3) [5]. Related to authority abuse core offense, it is still debatable or uncertain because elements of abuse of authority could not be tested in the context of criminal law alone. Should the authorities of abuse test parameters based on the administrative law as well.

With so many acts of abuse of power which give rise to acts of corruption is, in fact, the Mall administration action by certain groups with a personal and specific orientation that is contrary to the principles of good governance. In addition, a more fundamental in this article, that the acts of corruption also blatantly basis with the ethics of public administration, be it a public organization ethics, ethics of public bureaucracy, as well as the ethics of personal/individual.

In a bid to realize the national system that is good, clean and open, then one of them appears the concept of "Open Government". With the concept of open government, the Government is expected to be more "open up" to the 
community so that it can hit the Mall administration actions, including corruption in it.

Talk about Open Government, in the last decade, governments around the world have created Open Government Data (OGD) repositories to make government data more accessible and usable by the public. The OGD movement has been motivated by values such as improved government transparency, citizen collaboration and participation, and spurring innovation. Open government data is commonly defined as data produced with public resources and made publicly available with a license that allows for re-use and re-packaging in innovative applications. Although some definitions of OGD include a requirement to be machine-readable, for other perspectives it is sufficient to have a free use license. OGD practitioners have identified a quality standard based on the degree of data openness, with "five stars" OGD being available online, in structured formats, usable in free software packages, with web addresses or other uniform resource identifiers to enable users to locate data, and linked to other data to develop applications [6].

From the above exposure, at least minimally, there are two aspects of the absolute which must be reorganized to cultivate the power of intention and seriousness in anticorruption measures. The first is revamping and innovation national system. Both are also not less important is the overhaul of the public moral and ethical in every human resource in it. Problems of ethics are very important in considering simply put, ethics is basic standard value to reference everything that could be said to be right or wrong and good or bad.

Related to the public ethics, added again by Carol Lewis (in Cohen), sponsored by the American Society for Public Administration, sought to address this vexing problem of defining and applying public ethics. Lewis suggests that public ethics is different from personal ethics in terms of values and guiding principles. To Lewis, ethics is thinking systematically about morals and conduct and making judgments about right and wrong. In the public service, ethics must go beyond thinking about performance and action; hence public ethics comprises action-based judgments of right and wrong. To guide the public administrator in making such judgments, Lewis suggests using the concepts of responsibility and obligation from several perspectives, including a personal view, the perspective of humanity in general, a professional lens, the agency's goals and values, and the jurisdiction in which the decision is made [7].

George Frederickson in his book, Ethics and Public Administration, explained that the overall ethics in perspective, there are two schools of the dominant force in the human civilization. The perspective is a deontology approach and teleology approach [8]. The second perspective/approach which is the basis for determining an ethical footing it will come down to where.

First, deontology perspective (categorical imperative) led by Immanuel Kant, and second, the perspective of the teleology (hypothetical imperative) which one pioneered by John Stuart Mill. Deontology perspective focusing on what should be done based on instructions and norms that apply regardless of the consequences. Whereas teleology or commonly known with the concept of utilitarianism, prefer the impact or consequences of an action.

\section{RESEARCH METHODS}

This research can be classified as a literature review and critical research. The focus of this research is to review acts of corruption through the perspectives of the ethics of public administration theory and strategy of prevention. The researcher collected and analyzed data around two months. The data can be obtained by collecting literature data. The researcher collected materials from various sources, such as a scientific journal, book reports, research results, reference books, and other written documents related to the research focus as well.

\section{RESULTS AND DISCUSSION}

\section{A. The Ethics of Public Administration Theory Perspective in Reviewing Acts of Corruption}

From a variety of perspectives and approaches in the concept of ethics of public administration which put forward experts, in General, there are two major perspectives that we can make reference to the early and maybe we can expand again for reviewing acts of corruption in a variety of the world, including in Indonesia. The second perspective is the perspective of teleology and deontology perspective.

\section{Teleology Perspective}

Teleology comes from the word Greece "telos", meaning i.e. goals. Teleology ethics is indeed different from the ethics deontology ethics because teleology does not evaluate the behavior based on liability but on the basis of the purpose or result of any behavior. Are simply behaviors labeled either when it has a good cause and be good anyway? Instead, behaviors labeled bad when aiming and a bad result.

Teleology is the teaching which explains everything and all the events leading to the specific purpose. Teleology traditions, particularly related to the opinions of Mill and Bentham, often used in the context of modern utilitarianism. In this tradition, the decision was decided based on the consequences. This is also determined by the results that maximized, as security, happiness, pleasure, and dignity. The results could be assessed based on the individual, family, group or organization, environment, political jurisdictions, and the nation-state [8].

Teleology approach towards ethical administration rises to deny that what is good and bad or what should be done by the Administration, the main reference is the value of the benefit that would be obtained or generated, i.e. good or bad views from the consequences of a decision or action taken. In the context of State administration teleological approach about the good and bad of that, measured, among others, of the achievement of the goals of public policies (such as economic growth, health care, quality education, an opportunity to follow the environment), the fulfillment of society's choices or the embodiment of the power of the Organization, even if that individual power became the goal of his administration.

This approach also consists of various categories. There are two main ones. First, is what is called an ethical egoism, 
which seeks to develop a favor for him. Very known here is Niccolo Machiavelli, a bureaucrat Italy (Florence) in the 15th century, which advocated that power and personal survival is the goal of a government administrator. Second, utilitarianism, which is the starting point is the principle of utility, which is the best for putting as many people. This principle is already rooted for a long time, especially on the views of the 19th century, among others, of Jeremy Bentham and John Stuart Mills. However, in between egoism and utilitarianism, i.e., there are no sharp gap because a continuum, which of them can be placed, for example, the view that Weber a bureaucrat working for the real the interests of himself when he orders his superiors, by Cooper [9] called as "a disguised act of ego".

However, it has been estimated that in modern times and modern utilitarianism, the view of this group or this teleological approach to gain more attention. In view of this very subject matter is not paying attention to moral values, but the consequences in that administrative decisions and actions for the community.

The public interest is a measure of importance according to this approach. Here else encountered various problems. First, who determines whether something goals, size, or the desired results based on common interests, and not the interests of the decision makers themselves, or group, or groups that want to benefit. Second, where the location of the boundary between the rights of individuals with common interests. If the public interest reflected the interests of many individuals easily, then the problem is simple. However, if there is a sharp difference between the two, then it will be a problem. Third, how to make the right calculation that measures undertaken would benefit the public interest and not detrimental. This is important because of the strength of this approach (utilitarianism) is that in balance sheet the most of the benefits that must be obtained and the harm every detail, for the benefit of society as a whole. Or in other words efficiency.

\section{Deontology Perspective}

Deontology comes from the word Greece i.e. deon, which means liability. The ethics of moral guidelines in order to provide deontology man do what becomes an obligation in accordance with the values or norms. So, a behavior is judged good or bad based on the obligation that refers to values or moral norms. Donated and help others who are experiencing distress is a good action because it is a human duty to do so. On the contrary, sexual harassment and corruption are bad actions and the duty of man to avoid it.

This approach is based on the moral principles that must be upheld because of the truth that is in him and is not associated with a result or consequence of decisions or actions taken. The basis is that the administrative processes should be based on moral values which bind. This approach, however, is not only one of its stripes. The most fundamental is the view on the philosophy of Immanuel Kant (17241809), namely that the moral imperative and is categorical, that doesn't justify infringement thereon for any purpose, although because it harmed society or should fall a sacrifice. In the tradition of deontology, many people connect it with Aquinas and Kant, the decision is based on a duty or obligation is right or wrong, and the result is not relevant to the moral verdict [8]. From the explanation above it appears that the ethics deontology does not discuss what a result or consequence of a behavior. A behavior is justified not because of behavior that results in good behavior, but it does well and that behavior based obligations must be implemented.

According to Fox in the Cooper [9], among other things by bringing in three views that illustrate the approach this administration ethics in deontology. First, views on social justice, who appeared with the development of the "New public administration" (Frederickson and Hart, among others, 1985). According to this view, the State administration must be proactively encouraged the creation of equity or social equity. They see that the problems faced by the administration of the modern State are the existence of an imbalance in opportunity-rich, so they have the knowledge, and well organized, gain position always profitable in the State. In other words, the Administration must help the poor, who have less knowledge and not well organized. This view, developed enough, the academic world through many critics.

Second, what is called the present regime norms or values? This view was mainly sourced from Rohr in Lynch [10], who argues that the ethical State Administration should refer to values that are informing the State concerned. In this case, it refers to the Constitution should be the cornerstone of the ethics of the Administration in that country.

Third, the universal moral order or a universal moral order [11]. This view argues that there are moral values that are universal should be a handle for the public administrator. The problem here is no moral values was itself a lot of that is questionable because the various source and also culture and civilization, as has been described above.

Deontology theory paradigm is different to understand selfishness and utilitarianism, both of which are equally good rate as bad an Act provides benefits to either individual (egoism) or for many people/groups of society (utilitarianism), then the action was said to be ethical. Conversely, if the result of an act of harming individuals or the majority of groups of people, then that action is said to be unethical. The theory of judging an action based on the results, consequences, or the purpose of the Act is called the teleology theory.

Very different from the familiar teleology that rate the ethical or whether an action based on the results, goals, or the consequences of such action, is thus personalism deontology said that whether or not an act of ethical no connection at all with the goals, consequences, or the consequence of these actions. The consequences of an act should not be a consideration for assessing the ethical or whether an action.

\section{B. Enforcement and application of the ethics of public administration to minimize Corruption}

The Act of corruption, collusion and nepotism could appear anytime and anywhere along the road going between intention and chance encounters, such as what has been expressed earlier. The Act of corruption, collusion and nepotism can occur either on a high level of public bureaucracy, secondary or subordinate. Therefore to prevent or resolve acts of corruption, collusion, and nepotism in the bureaucracy of the public body must not attempt to reconcile between intention and opportunity. One of the 
efforts to prevent the merging between intention and no chance of yesteryear is upholding and enforcing ethics bureaucracy in the ranks of the public bureaucracy.

Corruption prevention comprises various means of action. Rieger [12] distinguish four types of prevention, as following: (a) Integrity and cooperation; (b) transparency and accountability; (c) reducing risks and opportunities; (d) control. Successful anticorruption strategies comprise prevention as well as a strong political commitment and leadership, a good legal framework, enforcement and punishment mechanisms, and training. In this work, we prefer to analyze the problem from an ethics perspective and so we will discuss ethics systems and their characteristics. Ethical Infrastructure of OECD (Organisation for Economic Co-operation and Development) will be presented as a good framework to be used in the analysis and the creation of countries ethical systems [3].

Next in the crime of corruption prevention efforts that more substantive is related human resources. Should the offender public administration, whether public officials or public administrator can increase the overall roles, functions, and responsibilities in each respective Government agencies. In order to enhance the role and contribute to the eradication of $\mathrm{CCN}$, every public administrator is required:

1. Political faith and have the intention to eradicate $K K N$ in earnest and consistent.

2. Increase the hard skills, soft skills, and his credibility is mainly in the field of institutions of Government.

Have high integrity and loyalty. Contain elements of integrity: honest, thoughtful, bold, and responsible.

- To be honest: the combination of firmness of soul contained principles of morality (peace of conscience), characters like the truth and openness (no cheating), liberality, the side of a gentle affection about ethics, justice, and truth.

- Wise: the attitude of always considering the following issues of the consequences carefully. For administrators of public interests such as more of a personal interest.

- Dare: cannot be intimidated by others, not subject to pressure is done by other people in order to influence attitudes and opinions. Courage can also be interpreted as capable of proposing the things according to the consideration and confidence need to be delivered. It can also be interpreted as having the attitude of a great confidence in facing various difficulties.

- Responsible: attitude did not swerve, not divert the blame on someone else, complete the task properly.

\section{CONCLUSION}

The application of ethics in everyday life or in the life of nation and State is absolute. Not only for personal or individual, ethics also compulsory applied in all sectors of life including the national sector, bureaucracy, or public administration. Filosofia the inception of ethics is because basically it's human nature there is good and bad. This is expressed in the book Frederickson Ethics and Public Administration, that human nature: good and bad, and that's what affects ethical decision making: true or false [8]. So ethics is human control tool in the Act and decide on action.

The focus of ethics in this article is the ethics of public administration. Public administration (public bureaucracy) as State agencies are carrying out the Mission of fulfilling the public interest demanded is responsible for the public it serves. There are three important concepts regarding the responsibility of the public against public administration, namely accountability, corporate responsibility, and responsiveness [13].

But in reality, not a few local officials (local bureaucracy) who have less accountability in the exercise of high duties, authority and responsibilities are given to him. As a result of the public bureaucracy on the reform era, many highlighted publicly. The spotlight was fixed on more deviant practices (mal-administration) from the ethics of State administration in carrying out its duties and responsibilities and he said. The form of mal-administration may take the form of corruption, collusion, nepotism, inefficient, and not professional. Forms of corruption generally have more to do with the behavior of the individuals who occupied an Office hierarchy, on the upper level to the lower level.

Seen from the perspective of the theory of ethics in public administration, be it a perspective of teleology as well as deontology, acts of corruption is the wrong action and very contrary to the ethics of public administration. In terms of the perspectives of teleology, in the purpose and consequences of acts of corruption, it's just for the benefit of individuals or groups/certain corporations and thus harming the public crowds, even detrimental to the finances of the State. In terms of deontology perspective, acts of corruption do not reflect the obligation and moral values that should be embedded in each element in the public administration, that is serving the public and responsible for the public with complete, corporate responsibility, accountability, and responsiveness.

In an effort to eradicate corruption, public administrators should have the intention and political faith to eradicate KKN insincerely and consistently, can raise the hard skills, soft skills, and his credibility is primarily in the field of institutions his Government, and has a high integrity and loyalty. The integrity of the containing element: honest, thoughtful, brave, and is responsible for it.

\section{ACKNOWLEDGMENT}

The authors would like to thank Galih W. Pradana for his careful review and suggestions which helped to improve this editorial.

\section{REFERENCES}

[1] C. S. Bhayangkara, "13 The Unfinished Case of KPK, Number 10 Has Been Snapped by the Chairman of BPK," Okezone News, 2018. [Online]. Available: https://news.okezone.com/read/2018/04/17/337/ 1887544/ 13-kasus-yang-belum-diselesaikan-kpk-nomor-10-sempatjerat-ketua-bpk?page=1. [Accessed: 02-Jul-2018].

[2] “Anti-Corruption Glossary," Transparency International, 2018. [Online]. Available: https://www.transparency.org/ glossary/term/corruption. [Accessed: 08-Jul-2018]. 
[3] S. Firmino, "Corruption and Quality of Democracy: Building Citizens' Trust through Ethics and Integrity," ECPR Grad. Conf., pp. $1-18,2010$.

[4] I. M. Islamy, Principles of State Policy Formulation. Jakarta: Bumi Aksara, 1998

[5] G. Government of Indonesia, Laws of The Republic Indonesia Num. 31 Year 1999 about The Eradication of Corruption. Indonesia, 1999.

[6] M. Gascó-Hernández, E. G. Martin, L. Reggi, S. Pyo, and L. F. LunaReyes, "Promoting the use of open government data: Cases of training and engagement," Gov. Inf. Q., vol. 35, no. 2, pp. 233-242, 2018.

[7] S. Cohen and W. B. Eimicke, "Ethics and the Public Administrator," Ann. AAPSS, vol. 24, no. 4, pp. 96-108, 1995.

[8] H. G. Frederickson and R. K. Ghere, Ethics in Public Management, no. 43. University of Dayton, 2013.

[9] T. L. Cooper, Handbook of Administrative Ethics. New York: Marcel
Dekker, Inc, 1994.

[10] T. D. Lynch and P. L. Cruise, Handbook of Organization Theory and Management. FL: CRC Press, 2006.

[11] K. G. Denhardt, "The Ethics of Public Service: Resolving Moral Dilemmas in Public Organizations," Greenwood Press, Google, 1988. [Online]. Available: https://books.google.co.id/books/about/ The_Ethics_of_Public_Service.html?id=XLEI5wS9FhAC\&printsec=f rontcover\&source $=\mathrm{kp} \_$read_button\&redir_esc $=\mathrm{y} \# \mathrm{v}=$ onepage $\& \mathrm{q} \& \mathrm{f}=\mathrm{f}$ alse. [Accessed: 08-Jul-2018].

[12] H.-J. Rieger, "Prevention-a key factor in fighting corruption. The role of a new training concept," EGPA Annu. Conf. Bern, 31st August to 3 Sept. 2005, vol. 8, no. 1, pp. 1-14, 2005.

[13] M. Darwin, Theory of Public Organization. Yogyakarta: Universitas Gadjah Mada, 1997. 